\title{
Status of ABET Accreditation in the Arab World
}

\author{
Osama Marzouk \\ Department of Technical Engineering, University of Buraimi \\ PO Box 890, Post Code 512, Al Buraimi, Sultanate of Oman \\ E-mail: osama.m@uob.edu.om
}

Received: January 13, 2019

Accepted: March 26, 2019

Published: April 10, 2019

doi:10.5296/gjes.v5i1.14218

URL: https://doi.org/10.5296/gjes.v5i1.14218

\begin{abstract}
This work represents a short statistical survey of the ABET accreditation in the 22 Arab countries. The data about ABET accreditation are last-updated on October 1, 2017. We found that there are 11 Arab countries with ABET-accredited programs, totaling 358 programs. These programs are mostly at the bachelor level, and are housed in 62 institutions of higher education. In a descending order of the number of ABET accredited programs they have, these countries are: (1) Saudi Arabia, (2) United Arab Emirates, (3) Lebanon, (4) Kuwait, (5) Egypt, (6) Jordan, (7) Bahrain, (8 and 9) Palestine and Qatar, (10) Oman, and (11) Morocco. Only Saudi Arabia has ABET-accredited programs at the master's level. Kuwait and Saudi Arabia are the only countries in the list that have ABET-accredited programs at the associate (diploma, 2-year) level. To account for the large variation of population for the considered countries, a relative scale for comparisons is introduced on a per-capita basis, and we calculated it utilizing the United Nations population data of July 1, 2015. We found that the ABET capita index varies from 4.91 (Bahrain) to 0.05 (Morocco) for the considered 11 Arab countries
\end{abstract}

Keywords: ABET, Accreditation, Arab, College, Education 


\section{Introduction}

While having governmental licensure is what a higher education institution needs to operate, extra features add to the strength and attractiveness of the institution or its colleges or programs. Such features include affiliation with another notable institution and having local (national) or international accreditation (Kassebaum, Cutler, \& Eaglen, 1998; Roller, Andrews, \& Bovee, 2003; Dodd, 2004; Wergin, 2005; Codner \& Patil, 2007). In the latter case, an accreditation body is to assess the program or unit against a set of criteria (assuming that the program or unit is eligible for accreditation and meets minimum requirements). There are different accreditation bodies with international scope. We here consider one of the famous accreditation bodies in the areas of applied science, computing, engineering, and engineering technology, which is ABET (Al-Yahya \& Abdel-halim, 2013). ABET used to be named the Accreditation Board for Engineering and Technology, but in 2005 its formal name changed to just ABET. Its history goes back to 1932, where it was established initially as the Engineers' Council for Professional Development (ABET History, 2013), which was an engineering society focusing on education, accreditation, regulation, and professional development for engineering in the United States. It is headquartered in Baltimore, Maryland, USA.

ABET accredits programs (not colleges or institutions). As of October 1, 2017 (latest update at the time of preparing this manuscript), there are 4,028 ABET-accredited programs worldwide (ABET, 2018). These come under three levels: associate or diploma degree (typically 2 years), bachelor degree (typically 4 years), and master's degree (post-graduate).

\section{Objective and Methodology}

This study provides a quick overview of the ABET-accredited programs located in the 22 countries of the Arab world (CNN Library, 2013; League of Arab States, 2018), and how they are distributed by country and by level. We collect accreditation data through the online database of ABET, which is freely available without a need for log-in credentials. We then did some organization, processing, and graphing of data and drew some conclusions.

Comparing different countries in an absolute sense (like comparing the number of accredited programs) can be misleading given the large disparity in their populations. Thus, we also corrected the accreditation data to national populations (de facto population, regardless of citizenship or residence status). The population data have a date stamp of July 1, 2015 (latest available online at the time of preparing this manuscript), and they are made accessible to the public by the United Nations as of June 2017 (United Nations, 2017). When ranking the Arab countries based on the ABET-accredited programs in a relative sense, we get different and fairer ranking than the one resulting from an absolute assessment.

It is possible that the same program receives more than one ABET accreditation as long as it can satisfy the accreditation criteria specific to each type of accreditation. For example, a program in (Industrial and Management Engineering) can be accredited as an Industrial Engineering program as well as an Engineering Management program. In such cases, we count the two accreditation separately and do not merge them. A branch of a mother 
institution is counted as a separate institution. An institution having ABET-accredited program at two or all the three different level is counted only once.

\section{Aggregate Overview}

Table 1 shows an integrated summary of the ABET accreditation in the Arab world. There are 358 ABET-accredited programs housed in 62 institutions of higher education in 11 Arab countries (out of 22 countries). The overwhelming majority (315 out of 358, or $88.0 \%$ ) of these programs are at the bachelor level. However, this high proportion agrees with the worldwide case $(3,669$ out of 4,028 , or $91.1 \%)$.

Table 1. Summary of overall ABET accreditation in the Arab world (as of 1/Oct/2017, dual-accredited programs are counted twice, an institution having accredited programs at more than one level is counted only once)

\begin{tabular}{|c|c|c|c|c|c|}
\hline Countries & Institutions & $\begin{array}{c}\text { Programs } \\
\text { (All Levels) }\end{array}$ & $\begin{array}{c}\text { Associate } \\
\text { (Diploma) Level }\end{array}$ & $\begin{array}{c}\text { Bachelor } \\
\text { Level }\end{array}$ & Master's Level \\
\hline 11 & 62 & 358 & 37 & 315 & 6 \\
\hline Worldwide & 4,028 & 279 & 3,669 & 80 \\
\hline Percentage of worldwide & $8.9 \%$ & $13.3 \%$ & $8.6 \%$ & $7.5 \%$ \\
\hline
\end{tabular}

Relative to the worldwide ABET accreditation, the share of the considered 11 Arab countries in the accredited programs is overall $8.9 \%$. This ratio seems promising given that the population ratio of the considered 11 Arab countries to the worldwide population is about $2.7 \%$ only (based on 1/July/2015 data).

In alphabetical order, the 11 Arab countries that have any ABET-accredited programs are: Bahrain, Egypt, Jordan, Kuwait, Lebanon, Morocco, Oman, Palestine, Qatar, Saudi Arabia, and United Arab Emirates. In alphabetical order, the other 11 Arab countries with no ABET accreditation at all are: Algeria, Comoros Islands, Djibouti, Iraq, Libya, Mauritania, Syria, Somalia, Sudan, Tunisia, Yemen.

\section{Distribution of Institutions}

The distribution of the 62 institutions offering ABET-accredited programs in the 11 Arab countries under consideration here is demonstrated graphically in Figure 1. Saudi Arabia comes at the top of the list with 20 institutions and then comes United Arab Emirates, with 16 institutions. Together, these two countries have more than half $(58.1 \%)$ of these institutions of higher education, although population-wise, they score only $20.3 \%$ collectively with regard to the 11 Arab countries. 


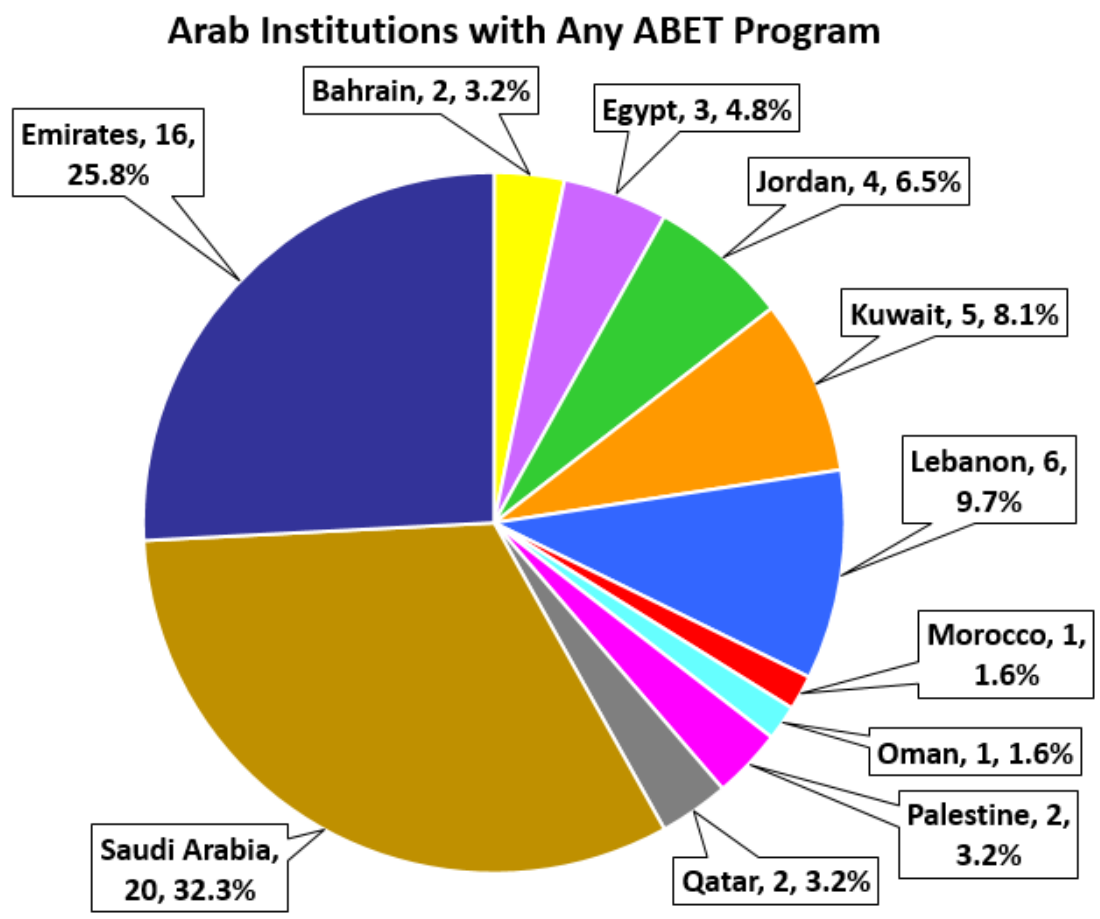

Figure 1. Number and percentage of institutions of higher education in the Arab countries that have any ABET-accredited program (as of 1/Oct/2017, repetitions at different program levels are not counted)

\section{Distribution of Programs}

Table 2 shows how the 358 ABET-accredited programs in the 11 Arab countries are distributed both by country and by program level. Only Kuwait ( 2 institutions) and Saudi Arabia (3 institutions) utilize ABET accreditation for associate-degree programs. These are normally accredited by the (Engineering Technology) accreditation commission of ABET, and in that case they must have the word (Technology) in the program title. We here give one example from each respective institution -- Boiler \& Turbine Operation Technology (High Institute of Energy, Kuwait), Electrical Machinery Technology (College of Technological Studies, Kuwait), Non-Destructive Testing and Evaluation Engineering Technology (Jubail Industrial College, Saudi Arabia), Electrical and Electronics Engineering Technology (King Fahd University of Petroleum and Minerals, Saudi Arabia), and Process Operations and Chemical Analysis Technology (Yanbu Industrial College, Saudi Arabia).

In the case of Kuwait, the two institutions offering ABET-accredited programs at the associate level do not offer similar programs at the bachelor level. On the other hand, all three institutions in Saudi Arabia that offer ABET-accredited programs at the associate level also offer ABET-accredited programs at the bachelor level, and one (King Fahd University of Petroleum and Minerals) even offers ABET-accredited programs at the master's level. This is the only Arab institution with ABET-accredited programs at the master's level. 


\section{Al Macrothink}

Global Journal of Educational Studies

ISSN 2377-3936

2019, Vol. 5, No. 1

Table 2. Distribution of ABET accredited programs in the Arab countries (as of 1/Oct/2017, dual-accredited programs are counted twice)

\begin{tabular}{|c|c|c|c|c|c|}
\hline $\begin{array}{l}\text { Serial } \\
\text { number }\end{array}$ & $\begin{array}{c}\text { Country (alphabetical } \\
\text { order) }\end{array}$ & $\begin{array}{l}\text { Associate } \\
\text { (diploma) }\end{array}$ & Bachelor & Master & $\begin{array}{l}\text { Rank Based on the } \\
\text { Number of All Programs }\end{array}$ \\
\hline 1 & Bahrain & & 12 & & 7 \\
\hline 2 & Egypt & & 20 & & 5 \\
\hline 3 & Jordan & & 17 & & 6 \\
\hline 4 & Kuwait & 13 & 11 & & 4 \\
\hline 5 & Lebanon & & 36 & & 3 \\
\hline 6 & Morocco & & 3 & & 11 \\
\hline 7 & Oman & & 9 & & 10 \\
\hline 8 & Palestine & & 11 & & $8 / 9$ \\
\hline 9 & Qatar & & 11 & & $8 / 9$ \\
\hline 10 & Saudi Arabia & 24 & 116 & 6 & 1 \\
\hline 11 & $\begin{array}{l}\text { United Arab } \\
\text { Emirates }\end{array}$ & & 69 & & 2 \\
\hline- & SUM & 37 & 315 & 6 & \\
\hline
\end{tabular}

Figures 2 and 3 further demonstrate the distribution of ABET-accredited programs among the relevant Arab countries. Figure 2 considers all three levels of programs, whereas Figure 3 considers only the bachelor level, which is the mainstream level for ABET accreditation, both regionally and globally. Similar to the distribution based on the number of institutions, Saudi Arabia ranks first in terms of the number of ABET-accredited programs $(146,40.8 \%)$ and United Arab Emirates comes in the second place. Both countries together have about $60 \%$ of the ABET-accredited programs in the 11 Arab countries.

In Egypt, Kuwait, Lebanon, Saudi Arabia, and United Arab Emirates, we found instances of dual and even triple accreditation, where the same program receives accreditation under two or three ABET criteria, benefiting from the similarity of these criteria that enables the program to meet them collectively. Such instances are 3 in Egypt, 1 in Kuwait, 5 in Lebanon, 9 in Saudi Arabia, and 2 in United Arab Emirates. 
All ABET Programs by Arab Countries

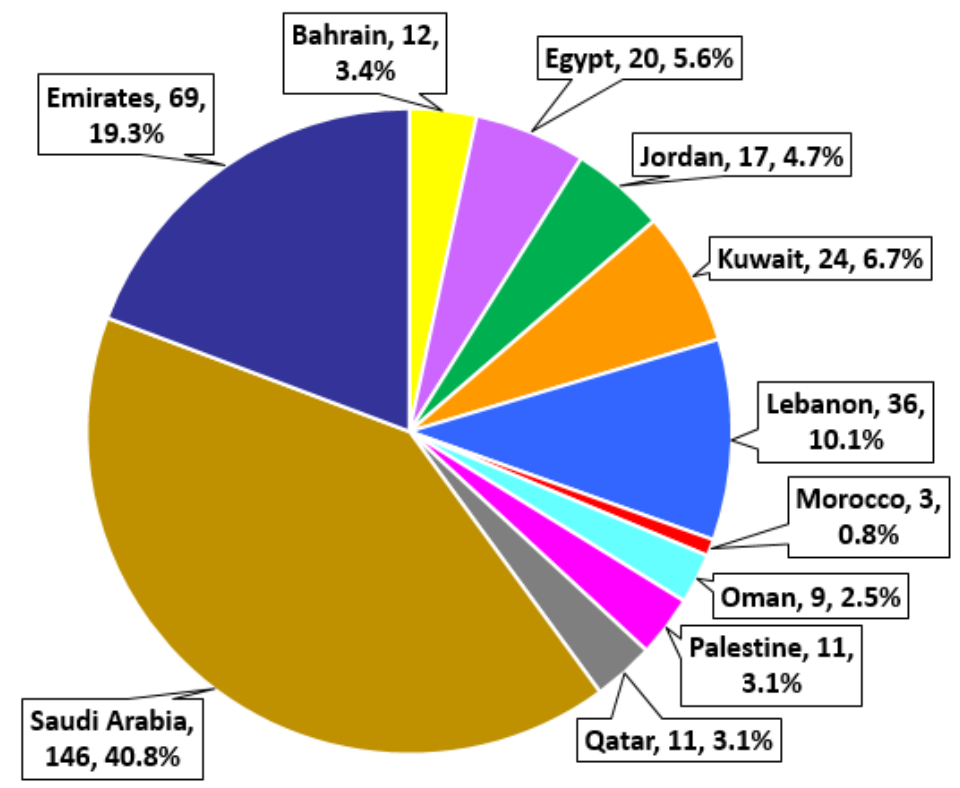

Figure 2. Distribution of all ABET-accredited programs in the 11 Arab countries with ABET accreditation (as of 1/Oct/2017, dual-accredited programs are counted twice)

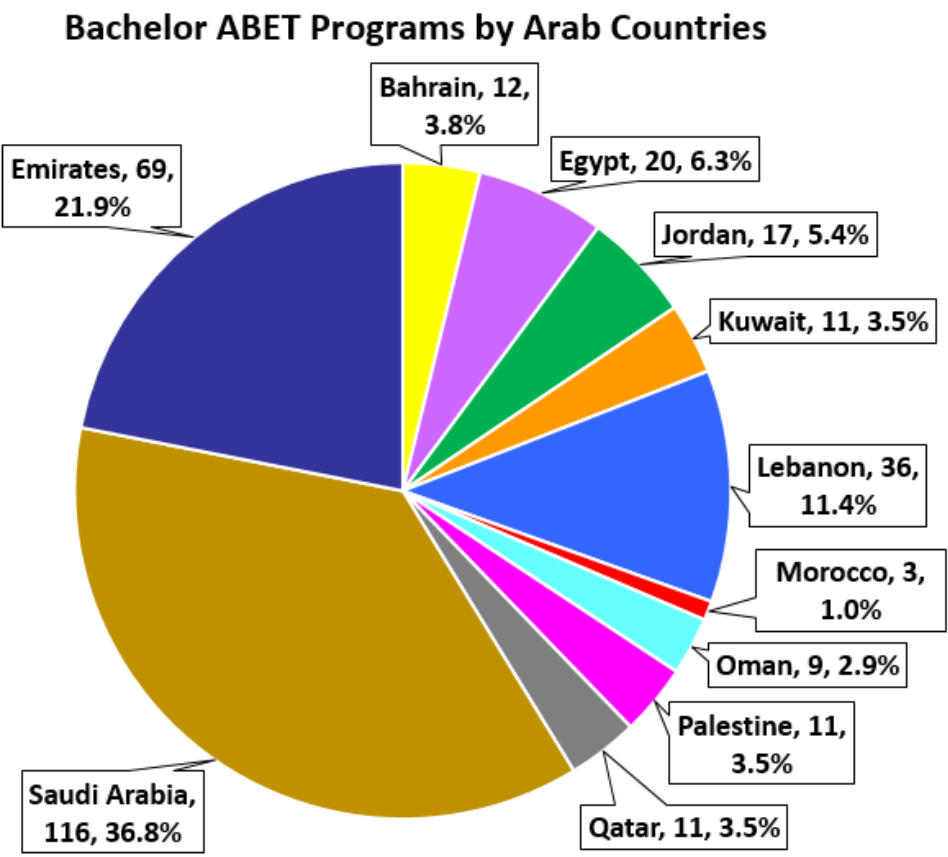

Figure 3. Distribution of ABET-accredited bachelor programs in the 11 Arab countries with ABET accreditation (as of 1/Oct/2017, dual-accredited programs are counted twice)

\section{ABET Capita Index}

The aforementioned comparisons between Arab countries in terms of their involvement in ABET accreditation should be viewed carefully as it is difficult to draw reliable conclusions based on such absolute comparisons in terms of counted number of programs or institutions 
alone without paying attention the large variation of population among the considered Arab countries. In order to address this point, a correction for population is proposed by introducing a per-capita index that is calculated as

$$
\text { ABET Capita Index }=\frac{\text { Accredited-Programs Share }}{\text { Population Share }}
$$

In Equation (1), the numerator is the population fraction for the country out of the total population in the 11 countries in the study $(200,955,603$ persons), and the denominator is a similar fraction but in terms of ABET-accredited programs at all levels. An index value of 1.0 corresponds to a matching between the overall population density and the accredited-programs density in all the 11 countries collectively. Therefore, an index value above 1.0 indicates relative superiority with respect to the average situation. Arab countries other than the 11 considered here have a value of 0.0 for that index.

Table 3 lists the values used in the calculation in the ABET capita index and the resulting index numbers. The ranking of countries changed to some extent, where Bahrain now comes at the top place with an index value of 4.91. The small population of Bahrain gives this country an advantage. United Arab Emirates still ranks the 2nd (as was the case in the absolute ranking). Lebanon comes in the 3rd place, then Kuwait, and then Saudi Arabia. Morocco ranked last in the absolute ranking and does so in this relative ranking.

Table 3. Calculation of the introduced ABET capita index for Arab countries

\begin{tabular}{|c|c|c|c|c|c|c|}
\hline $\begin{array}{c}\text { Serial } \\
\text { number }\end{array}$ & $\begin{array}{c}\text { Country } \\
\text { (alphabetical } \\
\text { order) }\end{array}$ & Population & $\begin{array}{c}\text { Population } \\
\text { Share }\end{array}$ & $\begin{array}{c}\text { Share of ABET } \\
\text { Programs (all } \\
\text { levels) }\end{array}$ & $\begin{array}{c}\text { ABET } \\
\text { Capita Index }\end{array}$ & Rank \\
\hline 1 & Bahrain & $1,371,855$ & $0.7 \%$ & $3.4 \%$ & 4.91 & 1 \\
\hline 2 & Egypt & $93,778,172$ & $46.7 \%$ & $5.6 \%$ & 0.12 & 10 \\
\hline 3 & Jordan & $9,159,302$ & $4.6 \%$ & $4.7 \%$ & 1.04 & 9 \\
\hline 4 & Kuwait & $3,935,794$ & $2.0 \%$ & $6.7 \%$ & 3.42 & 4 \\
\hline 5 & Lebanon & $5,851,479$ & $2.9 \%$ & $10.1 \%$ & 3.45 & 3 \\
\hline 6 & Morocco & $34,803,322$ & $17.3 \%$ & $0.8 \%$ & 0.05 & 11 \\
\hline 7 & Oman & $4,199,810$ & $2.1 \%$ & $2.5 \%$ & 1.20 & 8 \\
\hline 8 & Palestine & $4,662,884$ & $2.3 \%$ & $3.1 \%$ & 1.32 & 7 \\
\hline 9 & Qatar & $2,481,539$ & $1.2 \%$ & $3.1 \%$ & 2.49 & 6 \\
\hline 10 & Saudi Arabia & $31,557,144$ & $15.7 \%$ & $40.8 \%$ & 2.60 & 5 \\
\hline 11 & United Arab & $9,154,302$ & $4.6 \%$ & $19.3 \%$ & 4.23 & 2 \\
\hline
\end{tabular}




\section{Macrothink}

Global Journal of Educational Studies

ISSN 2377-3936 2019, Vol. 5, No. 1

Figures 4 and 5 give a visual overview of the relative comparison between the 11 counties under study, with Figure 4 showing the population and ABET-program fractions for each country, and Figure 5 showing the calculated ABET capita index, which is the result of dividing the fractions shown in Figure 4.

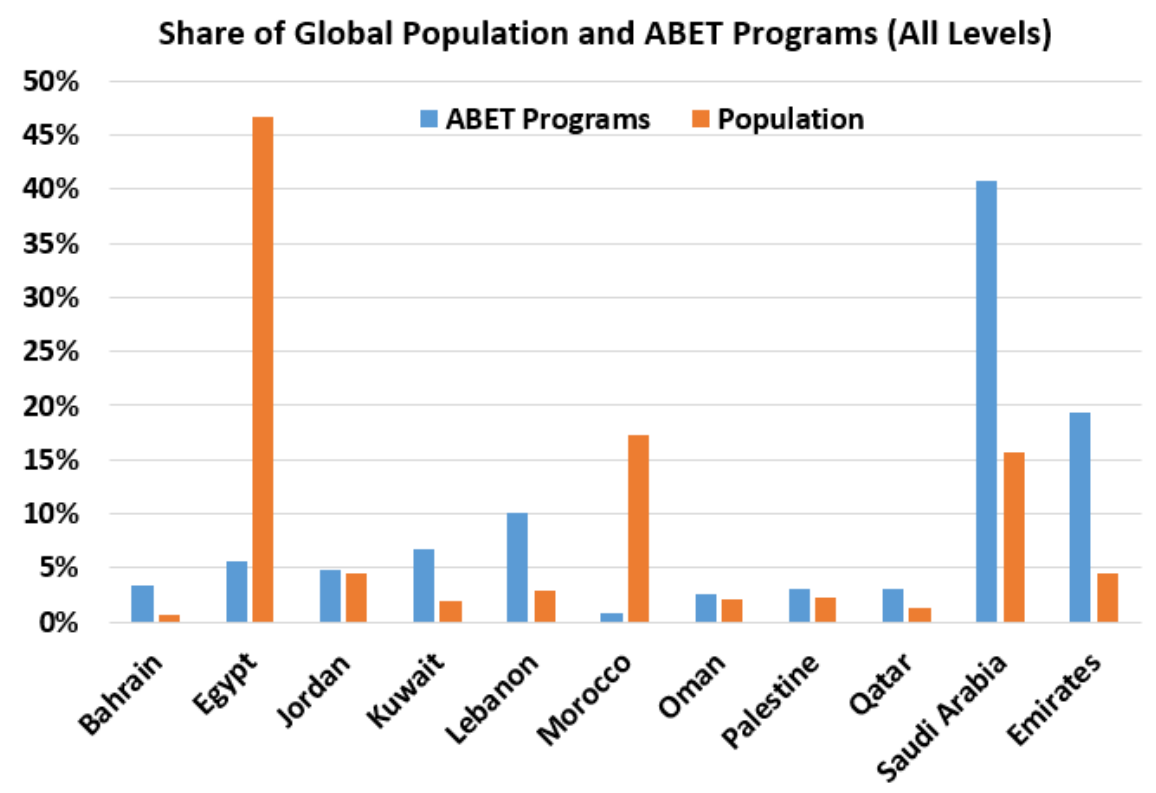

Figure 4. Comparison of the fraction of population (as of 1/July/2015) and ABET-accredited programs (as of 1/Oct/2017) in the Arab countries with ABET-accredited programs

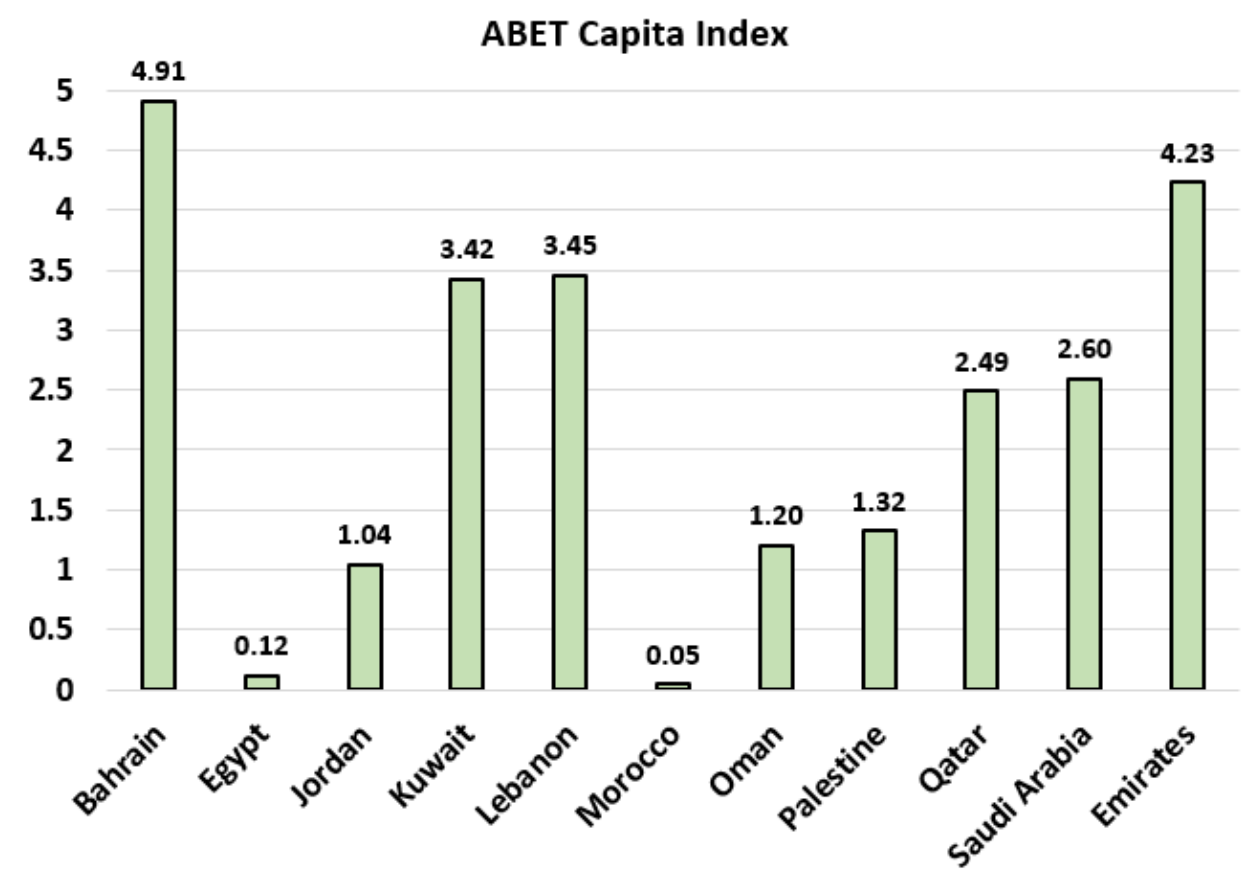

Figure 5. The introduced ABET capita index as calculated for the Arab countries with ABET-accredited programs 


\section{Conclusion}

This work gave a summary of the ABET accreditation in the Arab world, which can be of interest to a program new to accreditation and would like to select an accreditation body based on factors including its prevalence and popularity locally or regionally.

As of October 1, 2017, 11 Arab countries have ABET-accredited programs in one or more higher education institutions. These institutions have a total of 358 ABET accredited programs (out of 4,028 worldwide). Saudi Arabia and United Arab Emirates are the two major utilizers of ABET accreditation, and they together contribute about $60 \%$ of the ABET-accredited programs in the considered 11 Arab countries. Saudi Arabia is the only Arab country that has ABET-accredited programs at the master's level. It also has the highest number of institutions (20) and programs (146) with ABET accreditation. However, when considering the population factor, Saudi Arabia comes in the 5th place after Bahrain, United Arab Emirates, Lebanon, and Kuwait.

Dual and triple accreditation were found the most in Saudi Arabia (9 cases), then in Lebanon (5 cases). On the other hand, all ABET-accredited programs in Bahrain, Jordan, Morocco, Oman, Palestine, and Qatar are singly accredited.

\section{References}

ABET History. (2013). Retrieved from http://www.abet.org/History

ABET. (2018). ABET Accredited Program Search. Retrieved from http://main.abet.org/aps/Accreditedprogramsearch.aspx

Al-Yahya, S. A., \& Abdel-halim, M. A. (2013). A Successful Experience of ABET Accreditation of an Electrical Engineering Program. IEEE Transactions on Education, 56(2), 165-173. https://doi.org/10.1109/TE.2012.2206112

CNN Library. (2013). Arab League Fast Facts. Retrieved from https://edition.cnn.com/2013/07/30/world/meast/arab-league-fast-facts/index.html

Codner, G., \& Patil, A. (2007). Accreditation of engineering education: Review, observations and proposal for global accreditation. European Journal of Engineering Education, 32(6), 639-651. https://doi.org/10.1080/03043790701520594

Dodd, A. H. (2004). Accreditation as a catalyst for institutional effectiveness. New Directions for Institutional Research, (123), 13-25. https://doi.org/10.1002/ir.116

Kassebaum, D. G., Cutler, E. R., \& Eaglen, R. H. (1998). On the importance and validity of medical accreditation standards. J. American Medical Colleges, 73(5), 550-564. https://doi.org/10.1097/00001888-199805000-00027

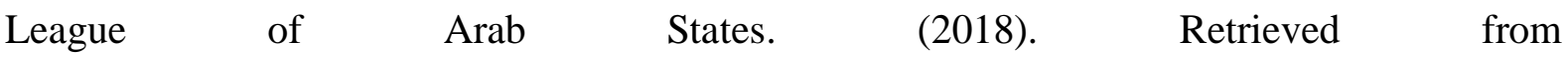
http://www.lasportal.org/ar/aboutlas/Pages/CountryData.aspx

Roller, R. H., Andrews, B. K., \& Bovee, S. L. (2003). Specialized Accreditation of Business Schools: A Comparison of Alternative Costs, Benefits, and Motivations. J. Education for 


\section{Macrothink \\ Global Journal of Educational Studies \\ ISSN 2377-3936 2019, Vol. 5, No. 1}

Business, 78(4), 197-204. https://doi.org/10.1080/08832320309598601

United Nations. (2017). Department of Economic and Social Affairs, Population Division, World Population Prospects: The 2017 Revision, DVD Edition, June 2017.

Wergin, J. F. (2005). Resource Review: Higher Education: Waking up to the Importance of Accreditation. Change, 37(3), 35-41.

\section{Copyright Disclaimer}

Copyright for this article is retained by the author(s), with first publication rights granted to the journal.

This is an open-access article distributed under the terms and conditions of the Creative Commons Attribution license (http://creativecommons.org/licenses/by/3.0/). 